\title{
Propolis extract in the diet of weaned piglets
}

\author{
Liliane Maria Piano Gonçalves ${ }^{1}$ Charles Kiefer ${ }^{*}$ Camilla Mendonça Silva $^{1}$ \\ Cássia Rejane Brito Leal ${ }^{1}$ Stephan Alexander da Silva Alencar ${ }^{1}$ \\ Kelly Cristina Nunes Carvalho ${ }^{1}$ Luciana Moura Rufino ${ }^{1}$
}

${ }^{1}$ Universidade Federal de Mato Grosso do Sul (UFMS), 97070-900, Campo Grande, MS, Brasil. E-mail: charles.kiefer@ufms.br. "Corresponding author.

ABSTRACT: This study was conducted to assess the use of propolis ethanolic extract as an alternative to performance-enhancing antibiotics for piglets. Seventy piglets weaned at 21 days of age, with initial weights of $7.3 \pm 0.4 \mathrm{~kg}$ and final weights of $24.9 \pm 1.2 \mathrm{~kg}$, were randomly assigned to five diets: positive control (diet with 200ppm antibiotic); negative control (diet without growth promoter); and diets with 100, 500, and 1,000ppm of brown propolis ethanolic extract, with seven replicates of two piglets each. The duration of the experimental period was 35 days. The diets did not influence $(P>0.05)$ daily feed intake, daily weight gain, final weight, and feed conversion of animals. The bacteriological profile of the nasal swab presented a predominance of gram-positive bacteria commonly associated with the mucous membranes in all samples. Rectal swabs did not present atypical bacterial isolates. The use of ethanolic propolis extract in diets did not alter the performance of weaned piglets, nor did it affect the bacteriological profile, fecal score, or the occurrence of diarrhea in piglets.

Key words: antimicrobials, diarrhea, ethanolic extract, vegetable extract.

\section{Extrato de própolis na dieta de leitões desmamados}

RESUMO: Esta pesquisa foi realizada com o objetivo de investigar a utilização de extrato etanóico de própolis como alternativa aos antibióticos melhoradores de desempenho para leitões. Foram avaliados 70 leitões desmamados aos 21 dias de idade, com pesos iniciais de

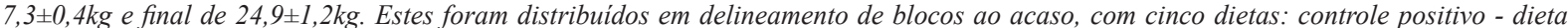
com 200ppm de antibiótico; controle negativo - dieta sem promotor de crescimento; dietas com 100, 500 e 1.000 ppm de extrato etanóico de própolis marrom, com sete repetições de dois leitões cada. A duração do período experimental foi de 35 dias. As dietas não influenciaram $(P>0,05)$ no consumo de ração diária, ganho de peso diário, peso final e a conversão alimentar dos animais. O perfil bacteriológico da swab nasal apresentou predomínio de bactérias Gram positivas comumente associadas às membranas das mucosas em todas as coletas realizadas. As swabs retais não apresentaram isolamento atípico. A utilização do extrato etanóico de própolis nas dietas não altera o desempenho de leitões desmamados, bem como não afeta o perfil bacteriológico, escore fecal e a ocorrência de diarreia dos leitões.

Palavras-chave: antimicrobianos, diarreia, extrato etanóico, extrato vegetal.

\section{INTRODUCTION}

The addition of performance-enhancing antibiotics in pig feed has long been adopted to reduce the incidence of post-weaning diarrhea and to improve animal performance. However, the use of these compounds has been considered a risk factor for human health, because of the presence of antibiotic residues in food of animal origin, and thus an increase in the incidence of microbial resistance (BRAZ et al., 2011). Given these restrictions, the use of these additives in animal nutrition has been limited, inspiring the search for natural alternative additives.

One of the potential alternative to antibiotics is the plant extract of propolis, which has antimicrobial, antibiotic, immunostimulating, anti-inflammatory, healing, antifungal, antiviral, antiprotozoal, and antioxidant properties (COELHO et al., 2010). Pharmacological properties attributed to propolis are caused by phenolic compounds, such as flavonoids and phenolic acids, which may vary according to the species of bees and plants from which the raw materials were obtained, as well as the seasonality and type of collector used in the hives (DE-MELO, 2014).

In Brazilian samples of propolis, the phenolic compounds reported were artepillin $\mathrm{C}$ and hydroxycinnamic acid (PEREIRA et al., 2003). Despite the highly variable chemical composition, because of the large plant diversity used for its production (FISCHER, 2008), all propolis have 
antimicrobial activity, being the most cited and scientifically proven effect (SAWAYA et al., 2002).

Studies on the antibiotic properties of propolis have been conducted mainly in the areas of human and veterinary medicine, demonstrating efficient bacteriostatic and bactericidal activity against several genera of gram-positive and gram-negative bacteria (BIANCHINI \& BEDENDO, 1998; PINTO et al., 2003). In Brazil, few studies have been conducted on the biological activities of propolis in terms of zootechnical indexes. Thus, this study was conducted with the goal of investigating the use of ethanolic extract of propolis as an alternative to performanceenhancing antibiotics for weaned piglets.

\section{MATERIALS AND METHODS}

Seventy piglets (Duroc/Pietrain $\times$ Large White/Landrace), weaned at 21 days of age, with initial weights of $7.3 \pm 0.4 \mathrm{~kg}$ and final weight of $24.9 \pm 1.2 \mathrm{~kg}$ were used in the study. The animals were distributed in a randomized block design with five diets: positive control (diet with 200ppm of antibiotic); negative control (diet without growth promoter); diets with 100,500 , and $1,000 \mathrm{ppm}$ of ethanolic extract of brown propolis in liquid form, diluted in soybean oil. Seven replicates were used with two piglets per experimental unit. Initial weight of animals was taken into account for blocks formation.

Animals were housed in a nursery room, equipped with suspended cages with an area of $0.81 \mathrm{~m}^{2}$, equipped with a semi-automatic feeder and pacifier drinkers and complementary heating.

The temperature and the relative humidity of the air were monitored daily using a dry bulb and wet bulb and black globe thermometers, installed in the center of the room. The values recorded were converted to the black globe-humidity index (BGHI) to characterize the thermal environment. Mean values of ambient temperature, relative air humidity, black globe temperature and BGHI were $26.0 \pm 2.1^{\circ} \mathrm{C}, 87.3 \pm 5.3 \%$, $25.3 \pm 2.7^{\circ} \mathrm{C}$, and $75.4 \pm 3.3^{\circ} \mathrm{C}$, respectively. These data indicated that the temperatures were within the range considered as ideal for pigs in this category, from 22 to $26^{\circ} \mathrm{C}$ (KUMMER et al., 2009).

The experimental period lasted 35 days and was subdivided into three periods corresponding to the pre-initial I (1st to $14^{\text {th }}$ day), pre-initial II ( $15^{\text {th }}$ to $28^{\text {th }}$ day), and initial $\left(29^{\text {th }}\right.$ to $35^{\text {th }}$ day $)$ stages. The diets (Table 1) were isonutritious and formulated to meet the nutritional requirements proposed by ROSTAGNO et al. (2011) according to the category of animal used. Animals were weighed at the beginning and end of each experimental phase, to determine the daily weight gain, as were the rations, which were weighed at the beginning and at the end of each phase, per bay, to measure feed intake and feed conversion.

Bacteriological examinations were performed after nasal and rectal swab collections in two animals of each treatment at the beginning and end of each experimental phase $(1,14,28$, and 35 days), totaling 10 samples per phase. The samples were cultured in brain and heart infusion agar (BHI) and MacConkey agar. After 24h, the samples were subjected to morpho-tinctorial analysis and identification was performed by biochemical profiles in specific media for gram-negative and grampositive bacteria. Results of bacteriological tests were tabulated and used in the form of bacteriological profiles, according to BARCELLOS et al. (2009).

To calculate a stool consistency score, a visual evaluation was performed daily, morning and afternoon, with scores ranging from 0 to 3 for each animal: $0=$ solid stools; $1=$ pasty stools; $2=$ liquid/ pasty stool; and $3=$ liquid stools, as proposed by ALMEIDA et al. (2012). Only scores 2 and 3 indicated the occurrence of diarrhea. Thus, it was possible to calculate the frequency of days with occurrence of diarrhea in each evaluation period of the experiment.

Throughout the experimental period, all piglets with diarrhea were treated with antibiotics and marked to check the recurrence of diarrhea in the days following the medication and the need for medication repetition.

The performance variables (diary feed intake, daily weight gain, and final weight and feed conversion) were subjected to an analysis of variance (ANOVA) using the general linear model procedure, SAS statistical program, version 9.0, with $5 \%$ significance. The initial weight was used as covariable in the statistical model. The non-parametric Kruskal-Wallis test was used to compare the means of the fecal scores, the occurrence of diarrhea, and the antibiotic application, with 5\% significance.

\section{RESULTS AND DISCUSSION}

The consumption of daily feed, daily and total weight gain, and feed conversion of the animals in the experimental phases evaluated did not differ $(\mathrm{P}>0.05)$ between the diets studied (Table 2). ITO et al. (2009) reported that the addition of $0.4 \%$ of crude propolis in the diet of weaned piglets could reduce feed consumption and impair weight gain of the animals, because propolis can negatively affect the palatability of diets. However, results obtained for the consumption 
Table 1 - Centesimal and nutritional composition of experimental diets.

\begin{tabular}{|c|c|c|c|}
\hline \multirow{2}{*}{ Ingredients } & \multicolumn{3}{|c|}{-----------------------------------------------Phase----------------------------------------------- } \\
\hline & Pre-initial I & Pre-initial II & Initial \\
\hline Corn $(7.88 \%)$ & 52.000 & 60.280 & 63.787 \\
\hline Soybean meal $(46 \%)$ & 19.738 & 17.550 & 26.931 \\
\hline Whey powder & 10.000 & 8.000 & 0.000 \\
\hline Sugar & 5.000 & 4.000 & 0.000 \\
\hline Blood plasma & 4.000 & 2.000 & 1.000 \\
\hline Soy oil & 3.700 & 3.000 & 2.311 \\
\hline Dicalcium phosphate & 1.835 & 1.686 & 1.503 \\
\hline Limestone & 0.676 & 0.765 & 0.833 \\
\hline Vitamin-mineral premix ${ }^{1}$ & 0.400 & 0.400 & 0.400 \\
\hline Salt & 0.156 & 0.224 & 0.380 \\
\hline L-Lysine $\mathrm{HCl}$ & 0.666 & 0.748 & 0.299 \\
\hline DL-Methionine & 0.283 & 0.281 & 0.088 \\
\hline L-Threonine & 0.260 & 0.292 & 0.069 \\
\hline L-Tryptophan & 0.062 & 0.074 & 0.000 \\
\hline Inert (kaolin) ${ }^{*}$ & 1.225 & 0.700 & 2.400 \\
\hline \multicolumn{4}{|c|}{ 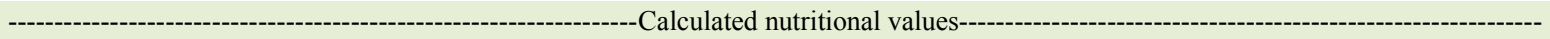 } \\
\hline Metabolizable energy $\left(\mathrm{Kcal} \mathrm{kg}^{-1}\right)$ & 3,400 & 3,375 & 3,230 \\
\hline Crude protein $(\%)$ & 20.00 & 20.00 & 19.24 \\
\hline Lysine digestible (\%) & 1.450 & 1.330 & 1.093 \\
\hline Meth+cyst digestible $(\%)$ & 0.812 & 0.745 & 0.612 \\
\hline Threonine digestible (\%) & 0.914 & 0.838 & 0.689 \\
\hline Tryptophan digestible (\%) & 0.261 & 0.239 & 0.197 \\
\hline Valine digestible (\%) & 1.001 & 0.918 & 0.754 \\
\hline Calcium (\%) & 0.850 & 0.825 & 0.768 \\
\hline Available phosphorus (\%) & 0.500 & 0.450 & 0.380 \\
\hline Sodium $(\%)$ & 0.280 & 0.230 & 0.200 \\
\hline
\end{tabular}

${ }^{1}$ Content per kilogram of product: vit. A - 1,250,000UI; vit. $\mathrm{D}_{3}-250,000 \mathrm{UI}$; vit. E - 6,250UI; vit. $\mathrm{K}_{3}-750 \mathrm{mg}$; vit. $\mathrm{B}_{1}-375 \mathrm{mg}$; vit. $\mathrm{B}_{2}-$ 1,000mg; vit. $\mathrm{B}_{6}-375 \mathrm{mg}$; vit. $\mathrm{B}_{12}-4,500 \mathrm{mcg}$; niacin - 4,500mg; pantothenic acid - 2,300mg; folic acid - 125mg; iron - 25g; copper $3,750 \mathrm{mg}$; manganese $-12.5 \mathrm{~g}$; zinc $-31.25 \mathrm{~g}$; iodine - 250mg; selenium - 75mg and excipient w.l.f. - 1,000g. "Halquinol was added to the diets instead of the inert (200ppm); The ethanoic extract of brown propolis was added to the diet replacing the inert (100, 500 and $1,000 \mathrm{ppm})$.

of diet in the present study indicated that the inclusion of up to $0.1 \%(1,000 \mathrm{ppm})$ of propolis extract did not alter the palatability of the diets and did not undermine the voluntary feed intake of animals.

Studies on the use of propolis and its byproducts as feed additives are scarce, especially with weaned piglets. No effects of propolis residues were observed on the weight gain of broiler chickens, from 1 to 42 days (SANTOS et al., 2003), and the authors explained the result with the high content of waxes $(26.8 \%)$ in the evaluated product. Young female rabbits fed diets with $1,000 \mathrm{ppm}$ of alcoholic extract of propolis displayed better performance, whereas those who received 3,000ppm of alcoholic extract of propolis displayed worse performance (GARCIA et al., 2004), probably because of changes in the animals' metabolism. According to the authors, the high levels of alcoholic extract of propolis may have caused a brief liver dysfunction which may have affected the efficiency in the utilization of nutrients in the diet.

In the present study, the diets containing antibiotic and propolis extract did not alter the performance of the piglets when compared to the negative control diet free of performance-enhancing additives. The lack of action of the antibiotic and the propolis extract as a growth enhancer can be explained by the low sanitary challenge conditions to which the animals were subjected during the experimental period, considering that it was the first use of the facility. 
Table 2 - Performance of piglets fed diets containing ethanoic propolis extract.

\begin{tabular}{|c|c|c|c|c|c|c|c|}
\hline \multirow{2}{*}{ Variables } & \multirow{2}{*}{$\begin{array}{l}\text { Positive } \\
\text { control }\end{array}$} & \multirow{2}{*}{$\begin{array}{c}\text { Negative } \\
\text { control }\end{array}$} & \multicolumn{3}{|c|}{ Propolis extract, ppm } & \multirow{2}{*}{$\mathrm{P}$ value } & \multirow{2}{*}{$\mathrm{CV}, \%$} \\
\hline & & & 100 & 500 & 1,000 & & \\
\hline \multicolumn{8}{|c|}{ 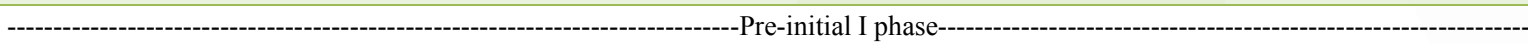 } \\
\hline Initial weight, $\mathrm{kg}$ & 7.38 & 7.29 & 7.16 & 7.38 & 7.32 & - & - \\
\hline Final weight, kg & 12.62 & 12.75 & 12.33 & 12.73 & 12.41 & 0.953 & 10.83 \\
\hline DFI, $\mathrm{kg}$ & 0.57 & 0.56 & 0.52 & 0.62 & 0.54 & 0.059 & 14.65 \\
\hline TWG, kg & 5.24 & 5.46 & 5.17 & 5.34 & 5.09 & 0.900 & 16.85 \\
\hline DWG, kg & 0.37 & 0.39 & 0.37 & 0.38 & 0.36 & 0.914 & 16.97 \\
\hline $\mathrm{FCR}, \mathrm{kg} \mathrm{kg}^{-1}$ & 1.54 & 1.46 & 1.42 & 1.63 & 1.53 & 0.194 & 13.99 \\
\hline \multicolumn{8}{|c|}{ 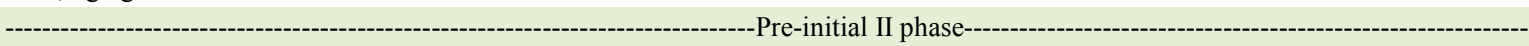 } \\
\hline Final weight, kg & 20.23 & 20.15 & 19.47 & 20.01 & 19.73 & 0.852 & 10.91 \\
\hline DFI, kg & 0.89 & 0.88 & 0.86 & 0.88 & 0.86 & 0.060 & 9.98 \\
\hline TWG, kg & 7.60 & 7.39 & 7.14 & 7.29 & 7.33 & 0.595 & 14.62 \\
\hline DWG, kg & 0.54 & 0.53 & 0.51 & 0.52 & 0.52 & 0.577 & 14.58 \\
\hline FCR, $\mathrm{kg} \mathrm{kg}^{-1}$ & 1.69 & 1.68 & 1.70 & 1.70 & 1.68 & 0.990 & 12.71 \\
\hline \multicolumn{8}{|c|}{ 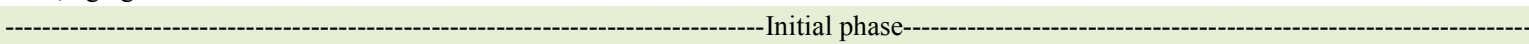 } \\
\hline Final weight, kg & 25.21 & 25.31 & 24.58 & 24.88 & 24.59 & 0.923 & 10.12 \\
\hline DFI, kg & 1.28 & 1.23 & 1.18 & 1.19 & 1.16 & 0.448 & 9.28 \\
\hline TWG, kg & 4.99 & 5.17 & 5.10 & 4.87 & 4.86 & 0.665 & 12.37 \\
\hline DWG, kg & 0.71 & 0.74 & 0.73 & 0.70 & 0.69 & 0.664 & 12.37 \\
\hline FCR, $\mathrm{kg} \mathrm{kg}^{-1}$ & 1.72 & 1.68 & 1.63 & 1.72 & 1.69 & 0.246 & 10.73 \\
\hline
\end{tabular}

DFI (daily feed intake), TWG (total weight gain); DWG (daily weight gain), FCR (feed conversion rate).

Bacteriological profile of piglets (Table 3) revealed that the presence of the antibiotics in the positive control diet did not prevent the growth of various strains of microorganisms. However, even with the presence of these strains the performance of the animals was not adversely affected. Results of bacteriological analyses of nasal swabs showed a predominance of gram-positive bacteria in all samples; however, there was no prevalence of any particular serious disease-causing strain at this stage. Some studies have shown that propolis has greater antibacterial activity against gram-positive than against gram-negative bacteria (PINTO et al., 2003). However, in the present study, the propolis extract showed no inhibitory activity on the gram-positive strains.

Therapeutic effects of propolis may be related to its chemical composition (SAMARA et al., 2011), such as the concentration of flavonoids, which could alter the cell membrane of the gram-positive bacteria, reducing ATP synthesis; consequently, reducing the pathogenic action of these bacteria (MANRIQUE et al., 2008). Composition of propolis can also be influenced by the flora of the region where it is produced (UCZAY et al., 2011), which may be one of the probable justifications for the variations observed in the different studies.
There was occurrence of Bordetella spp. in the $14^{\text {th }}$ day experimental samples from animals that received the diets containing propolis and negative control diets, demonstrating that propolis had no inhibitory effects on these species. Possibly because they belong to the group of gram-negative bacteria and in agreement with the literature (BIANCHINI \& BEDENDO, 1998; PINTO et al., 2003; SAMARA et al., 2011; UCZAY et al., 2011), propolis has a lower antibacterial activity against strains in this group, in comparison to gram-positive bacteria. However, the presence of this strain did not persist throughout the experimental period.

Result of the bacteriological analyses of rectal swabs showed no atypical isolates, but the presence and prevalence of strains of the bacteria Escherichia coli was observed in all treatments. However, only the presence and not the pathogenicity of the strains was verified; although, they were associated with enteric diseases (KUMMER et al., 2009). In a study that evaluated the effect of propolis ethanolic extract on the performance and immunity of poultry contaminated with $E$. coli strains, NARANJO et al. (2014) verified that supplementation with $0.4 \%$ of propolis extract in the drinking water improved some zootechnical parameters, such as feed conversion and animal weight, but without altering birds mortality. They 
Table 3 - Bacteriological profile of piglets fed diets containing ethanoic propolis extract.

\begin{tabular}{|c|c|c|}
\hline Diets & Nasal swabs & Rectal swabs \\
\hline \multicolumn{3}{|c|}{ 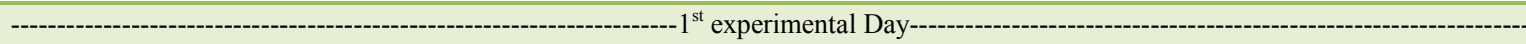 } \\
\hline Positive control & Bacillus, Streptococcus & E. agglomerans \\
\hline Negative control & Actinomyces, Streptococcus & E. coli \\
\hline Propolis 100ppm & Bacillus & E. coli, E. agglomerans \\
\hline Propolis 500ppm & Actinomyces & E. coli, E. agglomerans \\
\hline Propolis $1,000 \mathrm{ppm}$ & Pseudomonas,Streptococcus & E. coli \\
\hline \multicolumn{3}{|c|}{ - } \\
\hline Positive control & Micrococcus, Actinomyces, Levedura & E. agglomerans \\
\hline Negative control & Micrococcus, Bordetella, Corynebacterium & - \\
\hline Propolis 100ppm & Streptococcus, Bordetella, Corynebacterium & E. agglomerans, GNNF \\
\hline Propolis 500ppm & Bordetella, Streptococcus & E. coli \\
\hline Propolis $1,000 \mathrm{ppm}$ & Actinomyces, Bordetella, Corynebacterium & E. coli \\
\hline \multicolumn{3}{|c|}{ - } \\
\hline Positive control & Corynebacterium, GNNF, Micrococcus & $G N N F$ \\
\hline Negative control & Corynebacterium, GNNF, Micrococcus & E. agglomerans \\
\hline Propolis $100 \mathrm{ppm}$ & Corynebacterium, Micrococcus & GNNF \\
\hline Propolis 500ppm & Corynebacterium, Micrococcus & $G N N F$ \\
\hline Propolis $1,000 \mathrm{ppm}$ & Corynebacterium, Micrococcus & E. agglomerans \\
\hline \multicolumn{3}{|c|}{ - } \\
\hline Positive control & Corynebacterium, Actinomyces, S. aureus & E. coli \\
\hline Negative control & Corynebcterium, S.aureus & - \\
\hline Propolis 100ppm & Corynebcterium, S.aureus & E. coli, E. agglomerans \\
\hline Propolis 500ppm & Corynebcterium, S.aureus, Serratia, Actinomyces, Micrococcus & E. coli \\
\hline Propolis $1,000 \mathrm{ppm}$ & Corynebcterium, S.aureus & E. agglomerans \\
\hline
\end{tabular}

$\mathrm{GNNF}=$ Gram negative non-fermenter

also observed an immune stimulus in poultry treated with propolis and infected with E. coli strains. Because they belong to the group of gram-negative bacteria, these strains are more resistant to the action of antibiotics, because they have an additional external membrane and a periplasmic space that contains enzymes that can degrade xenobiotics (ALBUQUERQUE et al., 2014), such as flavonoids and phenolic acids from propolis.

In general, in the present study, the prevalence of most bacterial strains remained constant during the experimental period, possibly because of animals adaptation to the environment. In relation to the treatments evaluated, it was not possible to state that the addition of the ethanolic extract of propolis in diets demonstrated antibacterial effects in piglets.

There was no effect $(\mathrm{P}>0.05)$ of the experimental diets on the number and percentage of antibiotic applications (Table 4). Fecal scores and the occurrence of diarrhea were influenced $(\mathrm{P}<0.05)$ by treatments. In the pre-initial I phase, a greater $(\mathrm{P}<0.05)$ fecal score was observed in the piglets fed with the diet without promoter compared to the other diets. In the pre-initial II phase and initial phase, a higher $(\mathrm{P}<0.05)$ fecal score was observed in piglets fed with 500ppm of propolis extract compared that of the other diets. There was a higher occurrence of diarrhea in the treatment with $1,000 \mathrm{ppm}$ of ethanolic extract in the pre-initial II phase and lower occurrence in the treatment containing 500ppm of ethanolic extract in the initial I phase. Although, there were effects of the treatments on the fecal score and occurrence of diarrhea, it could be inferred that fecal scores ranged from 0.33 to 0.88 during the whole experimental period and the animals could be considered as non-diarrheal, according to the score proposed by ALMEIDA et al. (2012).

According to TAKAISI-KIKUNI et al. (1994), propolis disorganizes the cytoplasm, the cytoplasmic membrane, and the cell wall, causing partial bacteriolysis, thus inhibiting the protein synthesis of the gram-positive strains. In addition, constituents such as flavonoids and phenolic acids (e.g., caffeic acid), may influence the action of propolis as a growth enhancer in diets, because they deactivate energy formation in the cytoplasmic 
Table 4 - Fecal scores, occurrence of diarrhea and antibiotic application of piglets fed diets containing propolis ethanolic extract.

\begin{tabular}{|c|c|c|c|c|c|c|}
\hline \multirow{2}{*}{ Variables } & \multirow{2}{*}{$\begin{array}{c}\text { Positive } \\
\text { control }\end{array}$} & \multirow{2}{*}{$\begin{array}{c}\text { Negative } \\
\text { control }\end{array}$} & \multicolumn{3}{|c|}{ Propolis extract, ppm } & \multirow{2}{*}{$P$ value } \\
\hline & & & 100 & 500 & 1,000 & \\
\hline \multicolumn{7}{|c|}{ 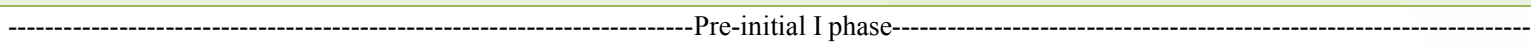 } \\
\hline Fecal score & $0.73 b$ & $0.88 \mathrm{a}$ & $0.62 b$ & $0.68 b$ & $0.60 \mathrm{~b}$ & 0.022 \\
\hline Occurrence of diarrhea, $\%$ & 5.27 & 5.25 & 4.74 & 5.01 & 4.52 & 0.371 \\
\hline Application of antibiotic & 0.05 & 0.062 & 0.022 & 0.02 & 0.05 & 0.574 \\
\hline Application of antibiotic, $\%$ & 2.77 & 3.12 & 1.08 & 2.61 & 1.43 & 0.574 \\
\hline \multicolumn{7}{|c|}{ - } \\
\hline Fecal score & $0.38 \mathrm{~b}$ & $0.41 \mathrm{~b}$ & $0.42 b$ & $0.53 \mathrm{a}$ & $0.33 b$ & 0.026 \\
\hline Occurrence of diarrhea, $\%$ & $4.25 b$ & $4.48 b$ & $4.04 \mathrm{~b}$ & $3.45 b$ & $5.14 \mathrm{a}$ & 0.010 \\
\hline Application of antibiotic & 0 & 0 & 0.01 & 0.01 & 0.01 & 0.856 \\
\hline Application of antibiotic, \% & 0 & 0 & 1 & 1 & 1 & 0.856 \\
\hline \multicolumn{7}{|c|}{--------------------------------------------------------------------------Initial phase--------------------------------------------------------------------------- } \\
\hline Fecal score & $0.61 \mathrm{~b}$ & $0.59 \mathrm{~b}$ & $0.59 \mathrm{~b}$ & $0.86 \mathrm{a}$ & $0.45 \mathrm{~b}$ & 0.001 \\
\hline Occurrence of diarrhea, $\%$ & $10.65 \mathrm{a}$ & $10.29 \mathrm{a}$ & $11.75 \mathrm{a}$ & $8.54 \mathrm{~b}$ & $11.67 \mathrm{a}$ & 0.038 \\
\hline Application of antibiotic & 0 & 0.01 & 0 & 0.01 & 0 & 0.537 \\
\hline Application of antibiotic, $\%$ & 0 & 0.47 & 0 & 0.44 & 0 & 0.537 \\
\hline
\end{tabular}

membrane and thus inhibit bacterial motility, making them more vulnerable to the immune system and favoring the antibacterial activity of propolis (PINTO et al., 2003). However, in the present study, no beneficial effects of the propolis ethanolic extract in piglets' diet were observed. Good sanitary and environmental conditions during the experiment were possibly the cause of the lack of response. The study would be more conclusive if, after introducing the propolis extract to the piglets, all the animals were challenged with pathogens, thus allowing a more effective evaluation of the antimicrobial and antibiotic action of propolis.

\section{CONCLUSION}

Use of the ethanolic extract of propolis in diets did not alter the performance of piglets when compared with the negative control diet. Inclusion of ethanolic extract of propolis did not change the bacteriological profile, score, and occurrence and need for the application of antibiotics. Further studies are needed on the inclusion of the ethanolic extract of propolis in the diet of piglets for a better understanding of their effectiveness as a performance enhancer.

\section{ACKNOWLEDGEMENTS}

To the Fundação de Apoio ao Desenvolvimento da Educação, Ciência e Tecnologia do Estado de Mato Grosso do Sul (FUNDECT), for granting the postdoctoral fellowship to Liliane Maria Piano Gonçalves and for research funding.

\section{BIOETHICS AND COMMITTE APPROVAL}

\section{BIOSSECURITY}

Project approved by the Ethics Committee on Animal Use under protocol no. 650/2014 - Universidade Federal de Mato Grosso do Sul (UFMS).

\section{REFERENCES}

ALMEIDA, E. et al. Effect of probiotic on the development of piglets challenged with Escherichia coli. Brazilian Journal of Veterinary Research and Animal Science, v.49, p.57-66, 2012. Available from: <http://189.126.110.61/BJVRAS/article/ view/541/514>. Accessed: March 28, 2017.

ALBUQUERQUE, C.H. et al. Flavonoid glycosides from Erythroxylum pulchrum A. St.-Hil. (Erythroxylaceae). Química Nova, v.37, p.663-666, 2014. Available from: <http://www. scielo.br/pdf/qn/v37n4/15.pdf>. Accessed: March 28, 2017. doi: 10.5935/0100-4042.20140104.

BARCELLOS, D.E.S.N. et al. Serological and bacteriological profiles in pig production. Acta Scientiae Veterinariae, v. 37 (Supl.1), p.117-128, 2009. Available from: $<$ http://www.lume.ufrgs. $\mathrm{br} / \mathrm{bitstream} /$ handle/10183/17458/000719137.pdf?sequence=1>. Accessed: July 16, 2015.

BIANCHINI, L.; BEDENDO, I.P. Antibiotic effect of propolis against plant pathogenic bacteria. Scientia Agrícola, v.55, p.149-152, 1998. Available from: <http://www.scielo.br/scielo. php? script=sci_arttext\&pid=S0103-90161998000100024>. Accessed: July 16, 2015. doi: 10.1590/S0103-90161998000100024.

BRAZ, D.B. et al. Acidifiers as alternatives to antimicrobial growth promoter of weanling pigs. Archivos de Zootecnia, v.60, 2011. Available from: http://scielo.isciii.es/scielo.php?script=sci arttext \&pid=S004-05922011003300662. Accessed: July 16, 2015. 
COELHO, M.S. et al. Propolis and its use in production animal. Archivos de Zootecnia, v.59, p.95-112, 2010. Available from: $<$ http://scielo.isciii. es/scielo.php?script=sci_arttext\&pid=S0004-05922011003300662>. Accessed: July 16, 2015.

DE-MELO, A.A.M. et al. Antioxidant activity of propolis. Pesquisa Agropecuária Tropical, v.44, p.341-348, 2014. Available from: $<$ http://www.scielo.br/pdf/pat/v44n3/a04v44n3.pdf $>$. Accessed: July 16, 2015.

FISCHER, G. et al. Immunomodulation induced by propolis. Arquivos do Instituto Biológico, v.75, p.247-253, 2008. Available from: <http://www.biologico.sp.gov.br/docs/arq/v75_2/fischer.pdf $>$. Accessed: July 16, 2015.

GARCIA, R.C. et al. Effect of the alcoholic extract of propolis on biochemical profile and performance of young female rabbits. Acta Scientiarum. Animal Sciences, v.26, p.57-67, 2004. Available from: <http://revistas.bvs-vet.org.br/actascianimsci/ article/download/10692/11438>. Accessed: July 16, 2015.

ITO, E.H. et al. Propolis use in the weaned piglets diets. PUBVET, v.3, artigo 361, 2009. Available from: < http://intranet.fca.unesp. $\mathrm{br} / \mathrm{mostra}$ cientifica/anteriores/2008/artigos/Zootecnia area/ Produção\%20Animal/1222173510trabalho_Resumo-ErikaSuino. pdf $>$. Accessed: July 16, 2015.

KUMMER, R. et al. Factors associated with nursery pig performance. Acta Scientiae Veterinariae, v.37, p.195-209, 2009. Available from: $<$ http://www.ufrgs.br/actavet/37-suple-1/suinos-22.pdf $>$. Accessed: July 17, 2015.

MANRIQUE A.J.; SANTANA, W.C. Flavonoids, antibacterial and antioxidant activities of propolis of stingless bees, Melipona quadrifasciata, Melipona Compressipes, Tetragonisca Angustula, and Nannotrigona $s p$. from Brazil and Venezuela. Zootecnia Tropical, v.26, n.2, p.157-66, 2008. Available from: $<$ http://www. bioline.org.br/request?zt08020>. Accessed: July 16, 2015.

NARANJO, F.S.; GONZALEZ, L.M.P. Evaluating ethanolic extract of propolis in broiler chicken development and immunity. Spei Domus, v.10, n.21, 2014. Available from: <http://revistas.ucc.edu.co/index. $\mathrm{php} / \mathrm{sp} / \mathrm{article} / \mathrm{view} / 915>$. Accessed: July 20, 2015. doi: 10.16925.

PEREIRA, A.S. et al. Distribution of quimic acid derivatives and other phenolic compounds in Brazilian propolis. Zeitschrift für
Naturforschung, v.58c, p.590-593, 2003. Available from: <http:// www.znaturforsch.com/ac/v58c/s58c0590.pdf>. Accessed: July $20,2015$.

PINTO, M.S. et al. Time kill curve of bacteria isolated from milk of cows with mastitis to three ethanolic extracts of propolis. Revista Brasileira de Ciência Veterinária, v.10, p.21-26, 2003. Available from: <http://www.uff.br/rbcv/ojs/index.php/rbcv/article/ download/1244/1140>. Accessed: March 28, 2017. doi: 10.4322/ rbcv.2015.261.

ROSTAGNO, H.S. et al. Brazilian tables for poultry and pigs: composition of foods and nutritional requirements. 3.ed. Viçosa: UFV, 2011. 252p

SAMARA, O. et al. Antibacterial activity and qualitative composition propolis from two climatic regions Cauca Department. Biotecnología en el Sector Agropecuario y Agroindustrial, v.9, p.8-16, 2011. Available from: < http://www.scielo.org.co/pdf/bsaa/ v9n1/v9n1a02.pdf $>$. Accessed: March 29, 2017.

SANTOS, E.L. et al. Nutritive value of propolis residue for broiler chikens. Ciência e Agrotecnologia, v.27, p.1152-1159, 2003. Available from: <http://www.scielo.br/scielo.php?script=sci artt ext\&pid=S1413-70542003000500025>. Accessed: July 16, 2015. doi: $10.1590 / \mathrm{S} 1413-70542003000500025$

SAWAYA, A.S.H.F. et al. Comparative study of in vitro methods used to analyse the activity of propolis extracts with different compositions against species of Candida. Letters in Applied Microbiology, v.35, p.203-207, 2002. Available from: <https:// www.ncbi.nlm.nih.gov/pubmed/12180941>. Accessed: July 16, 2015. doi: 12180941 .

TAKAISI-KIKUNI, B. et al. Electron microscopic and microcalorimetric investigations of the possible mechanism of the antibacterial action of a defined propolis provenance. Planta Médica, v.60, p.222-227, 1994. Available from: <https:// www.thieme-connect.com/DOI/DOI?10.1055/s-2006-959463>. Accessed: March 28, 2017. doi: 10.1055/s-2006-959463.

UCZAY, J. et al. Evaluation of propolis as growth promoter for the common carp (Cyprinus carpio). Revista Científica FCV-LUZ, v.21， p.408-413，2011. Available from: <http:// produccioncientificaluz.org/index.php/cientifica/article/ view/15666/15640>. Accessed: March 28, 2017. 